\author{
R. M. RUSIN ${ }^{1 *}$, I. V. LIASHENKO ${ }^{2 *}$ \\ ${ }^{1 *}$ Taras Shevchenko National University of Kyiv (Kyiv, Ukraine), e-mail rusinr71@ gmail.com, \\ ORCID 0000-0003-4102-0924 \\ ${ }^{2 *}$ Taras Shevchenko National University of Kyiv, (Kyiv, Ukraine), e-mail irina_lyashenko@univ.net.ua, \\ ORCID 0000-0003-3912-2075
}

\title{
EUROPEAN PLASTIC ART IN ANTHROPOLOGICAL DIMENSION: FROM THE CLASSICS TO THE POSTMODERNISM
}

Purpose. The article is devoted to the analysis of corporality as an attribute of plastic art in the Ancient art, the Middle Ages, the Renaissance, the modernism and the postmodernism. Theoretical basis. The authors consider historical development of the art as a change of paradigms. Within each paradigm a special understanding of art is created, which is characterized both by the act of creativity itself and by the evaluation of its results. Particularly urgent is the task to identify the origins of these changes, to indicate their stages, the direction of the evolution of artistic creativity. In this context, corporality as a paradigm of European plastic art is considered in the article in the concrete historical dimension from the classics to the postmodernism. Originality. Postmodern experiments stimulate blurring the borders between the traditional forms and genres of art. Review of canonical ideas about the creation and destruction, order and chaos in art illustrates conscious reorientation from the classical understanding of artistic creativity to the construction of artifacts-simulacra, which is a characteristic feature in the oeuvre of contemporary artists, ranging from the pop art to the present day. Conclusions. The ideas of postmodern philosophers found their visual embodiment in modern artistic practices. Reconstruction of the body, re-switching of its elements according to the principle of chaotic collage, the interpretation of the human body as a separate substance isolated from the individual him/herself, which is presented as a phenomenon of mass culture, became the basis of the creative method of contemporary plastic art. The ideas of postmodern philosophers have found their visual embodiment in the contemporary artistic practices.

Keywords: corporality; man; sculpture; classical art; modernism; postmodernism; artistic image

\section{Introduction}

The urgency of the research subject is conditioned by the changes that the art has undergone in recent centuries, not only from the point of view of plastic principles, but also in the aspect of being of a piece of art. The peculiarities of the modern artistic creativity have led to a situation of ambiguity in the understanding and evaluation of art pieces by contemporary artistic practices, philosophical and aesthetic concepts in the establishment of the principles of polystylistics and variability when constructing the artistic whole, and the declaration of the gap between the art of the past and the art of the twentieth and twenty first century, between classics, modernism, the avant-garde and postmodernism have questioned the notion of "art" itself. The real practice of art was an evidence of a fundamentally new situation in artistic life. It is no accident that today philosophy, aesthetics, art studies are increasingly paying attention to the real practice of art, a new artistic experience. At the same time, the versatility and ambiguity of the artistic process in various forms and areas of art requires clarification on the possibility of using today such concepts as "art", "piece of art", "plastic art".

The methodological ideas of O. Bazaluk (2015), V. Okorokov (2018), V. Khmil and A. Malivskyi (2017; 2018), V. Pryhodko and S. Rudenko (2018), S. Rudenko, Y. Sobolievskyi and V. Tytarenko (2018), and others were used when analyzing the corporality as an attribute of art, as well the corporality history in the European art. During the study of the anthropological measurement of the development of the European plastic art, the authors relied on hermeneutical 
methodology W. Dilthey, whose content was described by I. Liashenko (2018). The research of these authors is authoritative in this area, which is confirmed by the citation of their publications in the scientometric databases Scopus and Web of Science.

The main purpose of the article is the analysis of corporality as an attribute of plastic art in the Ancient Art, the Middle Ages, the Renaissance, modernism and postmodernism.

\section{Purpose}

To analyze corporality as an attributive characteristic of plastic art in ancient art, Middle Ages, Renaissance, modernism and postmodernism.

\section{Statement of basic material}

The notion of "art" is not given apriori, it is inseparable from the historical conditions of its own implementation and is filled with different content. In the ancient tradition, from which the theoretical conception of art originates, an understanding of art as a mimetic activity is envisaged. For the plastic art of the ancient Greeks, a man was the embodiment of all things in existence, a prototype of all that was created and is being created. The human body in its beautiful form was almost the only model of art, and, aesthetically, the Greeks thought of it in nothing but the statuary's completeness. In the ancient Greek culture, everything - space, state, and man is perceived through the category of corporality, which, according to the definition of $\mathrm{O}$. Losev (1979), goes far beyond the limits of the body, expanding to the limits of the sensory-material space. The body acts as an analogue of the universe; it retains all the forces of nature, the harmony of the physical elements. The body provides the human embeddedness into the integral system of the world, which itself is a perfect spiritualized body. A well-organized, beautiful human body is perceived as a reflection of cosmic energy. The ontological status of corporality elevates the beauty of the human body into a cult (Tsarenok, 2017).

Only among the Greeks all the elements of culture were in full harmony with nature, only in them there was a complete harmony of spirit and body, the pieces of art, in the living works of which the moral ideals of the people found for themselves understandable and enchanting expression. If the plastics of the East, for example Egypt, whose works of art are important for the history of culture, then in Greek, each piece of art gets a moral significance for all mankind, since the Greeks have risen to such a high stage of development that they have become a model for all times and peoples. This applies not only to Greek plastics, but also to poetry and architecture. The moral basis of Greek's pieces of art is the harmony and measure in everything that could appear in a society based on freedom, where the spirit is not related to dogmatic precepts, but freely acts in accordance with its own laws.

The spirit of freedom inspired everyone's strength, awakened activity in all areas of spiritual development. At the end of this era, the lyrical poetry is elevated to the solemn hymns of Pindar, and the art of tragedy - the genius of Aeschylus, Sophocles and Euripides reaches the highest value. The spirit of freedom also generates well-known artists in the field of plastic art: Phidias, Polykleitos, Skopas, Lysippos, and Praxiteles. These artists, starting from the origins, the antiquity revitalize ossified forms, make them flexible, and inhale a new spirit in them. They constantly improve art, bring it to the stage when it achieves complete liberation from traditional forms and is elevated to a higher degree of perfection, unity of the spiritual and corporal.

For Greek, the language of the body was the language of the soul, although ancient Greek plastic has not yet known that analysis of characters, the cult of an individual, which is so cha- 
racteristic of the art of the modern era. However, the Greeks were masters in the art of the transfer of typical psychology. Even the picture "Orpheus playing the lyre" is psychological. He transmits ecstasy, tenderness, movingness of the musician and his listeners. The ancient writers wrote about the Timomachus' picture "Medea" that the artist had expressed in it the duality of the soul, the struggle of two opposing feelings - jealous anger and pity for children. About the power of Praxiteles' "Erota" they wrote that he had struck only with the irresistible force of his languishing look, not with the arrows. As for the Pythagoras sculpture "Philoctetes", the audience complained about it: the sculptor portrayed Philoctetes lame so that they, looking at him, felt the pain themselves. A. Volynskiy (1992) characterizes ancient body as a body, which "speaks, sings on its own and screams sometimes louder and more complete than human words". "The eloquence of the body is a purely ancient viewpoint" (p. 29).

Plastic, kinetics of the ancient body can be regarded as components of a certain semantic structure, a special language, as a kind of mimicry. The plastic of the modern European sculpture shows the opposite to the antique classics inherent in the Christian tradition of the correlation of the soul and the body. The domination of the individualism positions in culture, the dominance of the spiritual image over the corporal leads to the fact that the body is reduced and the portrait begins to dominate the living figure. When, according to A. Volynskiy (1992), "people began to hide their bodies... the body lost its language. Plastic became simpler" (p. 30).

The internal individuality of a man has entered into its rights with the arrival of the Christianity. The corporal beauty lost its attractiveness and became a subject of contempt. The ultimate goal of art is now the expression of the spiritual purity, the sanctity of senses. This determined the purpose of painting and, obviously, took from the plastic its meaning in the ancient sense. If Antiquity did not know the duality of the spirit and body, and it did not imagine its gods otherwise except in the corporal embodiment, then Christianity brought dualism, legitimizing and introducing into the system a historically logical collapse of the early naive monism of the worldview. The gods became spiritual beings, free of flesh. John of Damascus in his "Three Treatises on the Divine Images: Apologia Against Those Who Decry Holy Images" proves that icon as an image is the reproduction of the divine "archetype". Therefore, when we worship an icon, we worship not matter, but the person who is portrayed, because the honor that we give to the image passes to the prototype. John of Damascus notes:

The image is likeness, and example, and the picture of something, indi-

cating the thing that was depicted on it. But as a whole the image is quite

similar to the first prototype, that is, the depicted thing or person, but one

is the image, and the second is the picture and the difference is quite ob-

vious, though both are the same. (Damascus, 1913, p. 399)

The nature of art in the aesthetic concept of Damascus (1913) is to glorify the intimate, divine, as the prototype of all existing. "Each image is the revelation and discovery of the hidden one" (p. 300), says J. Damascus. The corporal beauty in all its perfection, the picture of which was the purpose and content of plastics, lost its price to the first Christians. It even evoked their fear and disgust for the sensuality, which is so characteristic of the late Antiquity. 
It should be noted that the plastic was not completely supplanted from the Christian art, despite the disgust for it. Soon it tries to occupy a place in the lost area. It can achieve this by giving up its most important tasks. It obeys a new world view, forgets the perfect beauty of human forms, and sets the task to reflect the spiritual world of an individual, as an expression of a liberated, redeemed soul. The sculpture tries to express the inner world of man using its means of, his/her spiritual individuality with all its characteristic features, created by the new doctrine. This became possible when the empire of Charlemagne was broken up as a result of the unbridled desire of the Germanic tribes to freedom. And when these tribes declared their individual autonomy, they rejected the dogma of the Byzantine canon, democratizing it with a national attitude, the spirit of freedom revived plastic art and opened the way for its further development.

At the same time, it should be noted that the content of these artistic theological encyclopedias was so vague, allegorical and conditional that various plots and motives found a place in it. Allegories of sins and sinful passions were a convenient occasion to depict the fairy-tale, pagan monsters, who for the most part had no relation to the church concept of the universe. These amazing images came to the plastic art from pagan folk cults, fairy tales, animal epics and "settled" there for many centuries. These amazing images came to the plastic art of pagan folk worship, fairy tales, animal epics and "settled" there for many centuries. We very little understand in the medieval art, if we will not feel, will not appreciate the pathos of the earthly, simple, directly related to the life of ordinary people. People sympathized with Christ, because he suffered, as the poor suffer. They loved the Mother of God, because they saw her as advocatrice of ordinary people. Afterlife was imagined as earthly, only fairer.

If ancient statues claim that a beautiful spirit can only be in a beautiful body, then the statues of medieval temples, which are far from perfect corporal shapes, force us to think that only the spiritual light ennobles the body. The statues of Christ and Mary of the Cathedral in Reims do not seem to be ugly to anyone, they are definitely beautiful for everyone. Here, as compared to Antiquity the new thing is that the external beauty is perceived as a reflection of inner spiritual beauty. Even the medieval plastic most unattractive for us in its form seems clear and beautiful, as it is amazingly close to our world perception with its psychological truthfulness.

In the art of Europe in the Renaissance era, as a result of rethinking the Christian tradition of ancient experience, a tendency towards depicting the ideal body shapes, oriented to classical examples, is come up. Italian art, having liberated from spiritualism, which was the main feature of the Middle Ages, gradually got rid of the medieval plastic style, in which the manifestation of the mismatch in the content and form became more and more apparent and followed the path towards realism. The Renaissance era in contrast to the Middle Ages, having mastered the ancient architectural system created a "sculptural space" for plastics. In this space the plastic work could be opened in full beauty, could keep an independent meaning for itself, to become directly opposite to the architecture and connect with it in a general harmonious ensemble. The plastic of the Renaissance era took the shade of plastic determinacy of the Antiquity, transforming the human body by means of sculpture into perfect, giving it an individual spiritual certainty.

If an era guided by spiritualistic feelings begins to strive for the clarity and certainty of the form, then the first steps in this direction were made by sculpture. For it, creating its images of solid material, the need to bring them to life's truth appeared for the first time. Painting learns the results of plastic, and learns to depict its figures in space. At first, the sculpture pointed the path to the painting and led it, and then, in turn, yielded primacy to it. The painting, as predominantly the Christian art takes on the championship in this competition - it is clear by itself. It can to cover a huge amount of space with its images, awaken the viewer's interest better and 
faster. In addition, the variety of colors gives the opportunity to transmit emotional changes. Worldview attitudes for the perception of corporal as a secondary one explain the fact that neither Classicism nor Enlightenment, despite the fact that they were generally oriented toward Antiquity, did not become sculptural epochs.

In the middle of the nineteenth century, under the influence of a new look at human corporality, it takes place an appeal to Antiquity at a qualitatively new level in connection with the growing tendencies of human "naturalization" in culture and a critical attitude to previous historical periods. Its role in the process of returning to the body was also played by the strengthening in the irrational tendencies that came into conflict with the dominant "hyper-rationalism" with its human model, in which the hypertrophied reasonable beginning opposed the extra-essential, and therefore non-existent flesh. That is, a man-mind as the subject and man-body, as a passive object, were fundamentally separated (Aliaiev, \& Kutsepal, 2018; Okorokov, 2018). In the growing creativity, in search for new sculptural forms it is impossible not to see the roles of philosophy in general, and the ideas of A. Schopenhauer (1999) in particular. According to his concept, body is an incarnated will; it serves as the visibility of reality, which is contained in the will, which cannot be represented without a body: "The whole body is nothing but the objectification will, i.e., will that has become representation" (p. 23). Body appearance is embodied in a sculptural image and "power and completeness", its expression, exactly as "beauty and grace", which are interpreted by A. Schopenhauer, respectively, as the form of the will objectification in space and time are considered as the basic quality of the plastic image. Plastic art recognizes the ability to convey the movement of figures in space and time. The enrichment of the sculpture by dynamic coordinate was a challenge of time, a kind of reaction to the accelerated life pace. New ideas about speed actualize the dynamics of plastic image. It finds expression in the nature of images that under the influence of a dynamic moment are radically changing, for example, in futurism, cubism, expressionism. The deformation of the corporal motion as well as the body itself fully corresponds to new ideas about space, time and movement. Therefore, artistic reliability is unthinkable without deformation as a method of dynamic capture of procedurality (Khmil, \& Malivkyi, 2018).

A new construction of corporality is the basis for the formation of self-identity, where the body is the ascension point of modeling and involves the double projectivity of the physical and spiritual. The plastic image in the art has traditionally been focused on nourishing the corporal, this was understood as a natural form, the content of which was determined by the experience of viewer. The plasticity, for example, of Michelangelo's images, was interpreted in accordance with the plot, where Moses always remained Moses. In the interpretation of this work, S. Freud expresses the opinion only on the inner profound meaning of the prophet's gesture. The gesture is considered only as a sign placed in the "text" of the sculptural image. The sculpture of the twentieth century appeals to sensuality, the interpretation of the corporal form is not necessary. The spectator acquires an impulse of associative connections, where the artistic object will be conceived in the space of internal experience, in the structure of their own experiences.

Modernism was far from unambiguous, along with the recognition of colossal human possibilities, the freedom of individual, the space for the broad creative activity of modernism, according to J. Ortega y Gasset, it is also a "triumph over human", "loss of human quality", "humanity" of art and the world. The paradox of this situation is evidenced by the fact that in parallel with the increase in the value of an individual, it takes place a depreciation of human life in general. Along with the demarcation of demyurgical potentials of a man, there is a refusal to treat a man as a "mould" of God, and as a consequence, a radical rethinking of the very essence 
and direction of humanism. Characterizing contemporary art, J. Ortega y Gasset in his work "The Dehumanization of Art" wrote the following:

The art we talk about is inhumane, not only because it does not include

"human" things, but also because its activity is in dehumanization...

The point is not to paint something that would be completely different

from a man, a house or a mountain, but in order to paint a person who

would be like a man as little as possible... Aesthetic joy for a new artist

arises from this triumph "over human...". Looking for the most com-

mon generic and characteristic feature of the new creativity, I find the

tendency to dehumanize art. (Ortega y Gasset, 1991, p. 514)

And then: "All major epochs of art avoided the" human "as the center of gravity in their creations... So: styling means to deform the real, derealize. Stylization involves dehumanization" (Ortega y Gasset, 1991, p. 517).

In the culture of the twentieth century, the position of anthropological negativism is quite relevant. Justification of the value of an individual led to the lack of uniform norms, since the normative itself began to be perceived as an impingement on individuality. Decentralized culture addresses not to the formation of the ideal model, but to the consideration of the features that represent value as a deviation from the norm. According to this position, an artistic image is formed, which deviate from the "ideal" norms of beauty, from the clarity, completeness and integrity. In fact, such a plastic image ignores the shapes of the human body, going along the path of increasing dehumanization. Here we can observe the limit of the expressed firmness of the corporal image. It is this image the modern plastic image tries to deviate from, referring to the sensuality of the form, fragmentation, the destruction of harmonious unity. Destruction - creation is one of the most important principles of plastic, where the transformer's spectacularity owns the boundary expression, which stands for the modern metaphor of Thing-an-Sich (Thing-in-itself). The new type of dynamic relationship between the form and environment is fixed in the art of the futurists, and in particular in the Boccioni's sculpture, where the motive of the movement owns a form, violates its internal statics, stretches the figure along the "lines of force" and deforms it. Attempts to include the dynamic processes in the form becomes the reason for its destruction that is why at the time of the "animation" of the forms - let us recall the baroque - the deformation takes on a total nature. In the context of modernist art, the essence of which can be determined, using the words of P. Picasso as "the sum of destructions", the desire to denial, dismantling, elimination is the most widespread and manifests itself equally in the stylistics of works, and, for example, in the desire to overcome the just created. Thus, we can say that the distortion of the form fully corresponds to the modernism specificity and serves as an expression of its ascension tendencies oriented to negation. Postmodern corporality, semiotized, textually oriented and practically isomorphic to the textuality, subjected to symbolic dismemberment (Pstuszek, 2018). 
If we talk about the figurative expression of the concept of "body without organs", about the forms of its manifestation in the art, then, above all, one should mention H. Arp and the type of sculpture characteristic to him - "human nodules" or, in another version of the reading, "human concretions". This sculpture represents some natural object in the sense that its arsenal involve biomorphic forms, the slow flow of which reproduces the situation of "eternal flow" and transformation. Postmodernist experiments, both in theory and in artistic practices, deform the body, destroy its integrity, and at the same time the artistic-figurative system of art. The analysis of plastic art performed by J. Baudrillard answers the question whether everything that is created today as an art is in fact it and whether the term "art" can be applied to all phenomena of artistic culture? J. Baudrillard divides the artistic image into four main stages. At the first stage of its development, the image is a mirror that reflects the surrounding reality. At the second stage, reality begins to distort, at the third - to disguise its absence, and finally turns into a "simulacrum", a copy without the original, which exists by itself, without any relation to reality.

The term "art" is an abstraction. The real being of art is a work. It can obtain the status of art only in the event that it is based on an image as a universal paradigm that reveals its essence in all forms and genres. Therefore, not everything that claims to be included in the art today can be called the term "contemporary art". Operating with such a concept, we deliberately or unknowingly put the sign of equality between classical art and the phenomena of modern culture, far from the art. Exhibition organizers, art dealers, art historians should take into account this fact and call it all with its name, for example, an avant-garde exhibition, conceptualism, hyperrealism, abstractionism, etc. The versatile creative activity has the right to life, but the public also has the right to know what it can count on visiting such exhibitions.

\section{Originality}

The corporal beauty in all its perfection, the picture of which was the purpose and content of plastics of Antiquity and the Renaissance, lost its price and attractiveness in the art of postmodernism became the subject of disgust and contempt. Review of canonical ideas about the creation and destruction, order and chaos in art illustrates conscious reorientation from the classical understanding of artistic creativity to the construction of artifacts-simulacra, which is a characteristic feature in the oeuvre of contemporary artists, ranging from the pop art to the present day.

\section{Conclusions}

A theoretical and methodological reconstruction of the theoretical principles of philosophical postmodernism and postmodern aesthetic-artistic practices is carried out, which allows the following conclusion. Postmodern experiments stimulate blurring the borders between the traditional forms and genres of art. Review of canonical ideas about the creation and destruction, order and chaos in art illustrates conscious reorientation from the classical understanding of artistic creativity to the construction of artifacts-simulacra, which is a characteristic feature in the oeuvre of contemporary artists, ranging from the pop art to the present day. Reconstruction of the body, re-switching of its elements according to the principle of chaotic collage, the interpretation of the human body as a separate substance isolated from the individual him/herself, which is presented as a phenomenon of mass culture, became the basis of the creative method of contemporary plastic art. The ideas of postmodern philosophers have found their visual embodiment in the contemporary artistic practices. 
The ideas of the postmodern philosophers Jacques Derrida, Gilles Deleuze, Felix Guattari, Jean Baudrillard and others have found their visual embodiment in contemporary artistic practices. The corporal beauty in all its perfection, the picture of which was the purpose and content of plastics of Antiquity and the Renaissance, lost its price and attractiveness in the art of postmodernism became the subject of disgust and contempt.

\section{REFERENCES}

Aliaiev, G., \& Kutsepal, S. (2018). Nikolay Lossky's Cosmology. Philosophy and Cosmology, 20, 154-162. doi: 10.29202/phil-cosm/20/15 (in English)

Bazaluk, O. (2015). Postmodernism: Philosophy of Education. Future Human Image, 2(5), 9-22. (in Ukrainian)

Damascus, J. (1913). Polnoe sobranie tvoreniy Sv. John Damascus. St. Petersburg: Imperatorskaya SanktPeterburgskaya Dukhovnaya Akademiya. (in Russian)

Khmil, V., \& Malivkyi, A. (2017). Contemporary reception of Rene Descartes'skepticism. Philosophy and Cosmology, 19, 168-178. (in Ukrainian)

Khmil, V., \& Malivkyi, A. (2018). The problem of forms of completing the Copernicus revolution in modern Cartesian science. Philosophy and Cosmology, 21, 131-139. doi: 10.29202/phil-cosm/21/14 (in English)

Liashenko, I. (2018). Wilhelm Dilthey: Understanding the human world. Philosophy and Cosmology, 20, 163-169. doi: 10.29202/phil-cosm/20/16 (in English)

Losev, A. F. (1979). Istoriya antichnoy estetiki. Ranniy ellinizm. Moscow: Iskusstvo. (in Russian)

Okorokov, V. (2018). Limits of thought in the light of nature and Divinity. A return to ancient thought or the quest for the being of primordial thinking in the later Heidegger. Philosophy and Cosmology, 20, 170-184. doi: 10.29202/phil-cosm/20/17 (in English)

Ortega y Gasset, J. (1991). La deshumanización del arte. I. Terteryan, \& N. Matyash (Compilers), Trans. from Spanish. Moscow: Raduga. (in Russian)

Pryhodko, V., \& Rudenko, S. (2018). Body and space relationship in the research field of phenomenological anthropology: Blumenberg's criticism of Edmund Husserl's "Anthropology Phobia". Anthropological Measurements of Philosophical Research, 13, 30-40. doi: 10.15802/ampr.v0i13.125512 (in English)

Pstuszek, A. (2018). The social potential of the polish art in the transformation period. Future Human Image, 9, 82-91. doi: 10.29202/fhi/9/8 (in English)

Rudenko, S., Sobolievskyi, Y., \& Tytarenko, V. (2018). Cosmology in the philosophical education of Ukraine: History and modern condition. Philosophy and Cosmology, 20, 128-138. doi: 10.29202/phil-cosm/20/12 (in English)

Schopenhauer, A. (1999). Sobranie sochineniy. Die welt als wille und vorstellung (Vol. 1-6). Y. Aykhenvald, Trans. Moscow: TERRA - Knizhnyy Club; Respublika. (in Russian)

Tsarenok, A. (2017). The cosmological potential of byzantine ascetic aesthetics. Future Human Image, 8, 160-170. (in English)

Volynskiy, A. L. (1992). Kniga likovaniy: Azbuka klassicheskogo tantsa. Moscow: Artist. Rezhisser. Teatr. (in Russian)

\section{LIST OF REFERENCE LINKS}

Aliaiev, G. Nikolay Lossky's Cosmology / G. Aliaiev, S. Kutsepal // Philosophy and Cosmology. 2018. - Vol. 20. P. 154-162. doi: 10.29202/phil-cosm/20/15

Базалук, О. О. Постмодернізм: філософія освіти / О. О. Базалук // Future Human Image. - 2015. - № 2 (5). P. 9-22.

Дамаскин, И. Полное собрание творений Св. Иоанна Дамаскина / И. Дамаскин ; пер. с греч. - СанктПетербург : Имп. С.-Петерб. Духовная Акад., 1913. - Т. 1. - 442 с.

Хміль, В. В. Сучасна рецепція скептицизму Рене Декарта / В. В. Хміль, А. М. Малівський // Philosophy and Cosmology. - 2017. - Vol. 19. - P. 168-178.

Khmil, V. The Problem of Forms of Completing the Copernicus Revolution in Modern Cartesian Science / V. Khmil, A. Malivkyi // Philosophy and Cosmology. - 2018. - Vol. 21. - P. 131-139. doi: 10.29202/phil$\operatorname{cosm} / 21 / 14$ 
Liashenko, I. Wilhelm Dilthey: Understanding the Human World / I. Liashenko // Philosophy and Cosmology. 2018. - Vol. 20. - 163-169. doi: 10.29202/phil-cosm/20/16

Лосев, А. Ф. История античной эстетики. Ранний эллинизм / А. Ф. Лосев. - Москва : Искусство, 1979. $815 \mathrm{c}$.

Okorokov, V. Limits of Thought in the Light of Nature and Divinity. A Return to Ancient Thought or the Quest for the Being of Primordial Thinking in the Later Heidegger / V. Okorokov // Philosophy and Cosmology. 2018. - Vol. 20. - P. 170-184. doi: 10.29202/phil-cosm/20/17

Хосе Ортега-и-Гассет. Дегуманизация искусства / Хосе Ортега-и-Гассет ; сост. И. Тертерян, Н. Матяш ; пер. с испан. - Москва : Радуга, 1991. - 639 с. - (Серия: Антология литературно-эстетической мысли).

Pryhodko, V. Body and Space Relationship in the Research field of Phenomenological Anthropology: Blumenberg's Criticism of Edmund Husserl's "Anthropology Phobia" / V. Pryhodko, S. Rudenko // Антропологічні виміри філософських досліджень. - 2018. - Вип. 13. - С. 30 -40. doi: 10.15802/ampr.v0i13.125512

Pstuszek, A. The Social Potential of the Polish Art in the Transformation Period / A. Pstuszek // Future Human Image. - 2018. - Vol. 9. - P. 82-91. doi: 10.29202/fhi/9/8

Rudenko, S. Cosmology in the philosophical education of Ukraine: History and modern condition / S. Rudenko, Y. Sobolievskyi, V. Tytarenko // Philosophy and Cosmology. - 2018. - Vol. 20. - P. 128-138. doi: $10.29202 /$ phil-cosm/20/12

Шопенгауэр, А. Собрание сочинений : в 6 т. / А. Шопенгауэр ; пер. Ю. Айхенвальд. - Москва : ТЕРРА Книжный клуб ; Республика, 1999. - Том 1 : Мир как воля и представление. - 496 с.

Tsarenok, A. The Cosmological Potential of Byzantine Ascetic Aesthetics / A. Tsarenok // Future Human Image. 2017. - Vol. 8. - P. 160-170.

Волынский, А. Л. Книга ликований: Азбука классического танца / А. Волынский. - Москва : Артист. Режиссер. Театр, 1992. - 299 с.

\section{Р. М. РУСIH ${ }^{1 *}$, I. В. ЛЯШЕНКО ${ }^{2 *}$}

1*Київський національний університет імені Тараса Шевченка (Київ, Україна), ел. пошта rusinr71@ gmail.com, ORCID 0000-0003-4102-0924

${ }^{2 *}$ Київський національний університет імені Тараса Шевченка (Київ, Україна), ел. пошта irina_lyashenko@ univ.net.ua, ORCID 0000-0003-3912-2075

\section{ЄВРОПЕЙСЬКЕ ПЛАСТИЧНЕ МИСТЕЦТВО В АНТРОПОЛОГІЧНОМУ ВИМІРІ: ВІД КЛАСИКИ ДО ПОСТМОДЕРНІЗМУ}

Мета. Стаття присвячена розгляду тілесності як атрибутивної ознаки пластичного мистецтва в Античному мистецтві, Середньовіччі, Відродженні, модернізмі й постмодернізмі. Теоретичний базис. Історичний розвиток мистецтва розглядається авторами як зміна парадигм. В рамках кожної парадигми виробляється особливе розуміння мистецтва, що характеризується як самим актом творчості, так і оцінкою його результатів. Особливої актуальності набуває завдання виявити витоки цих змін, позначити їх етапи, спрямованість еволюції художньої творчості. У цьому контексті тілесність як парадигма європейського пластичного мистецтва розглядається в статті в конкретно-історичному вимірі від класики до постмодернізму. Наукова новизна. Постмодерністські експерименти стимулюють стирання меж між традиційними видами і жанрами мистецтва. Перегляд канонічних уявлень про творення й руйнування, порядок i хаос у мистецтві свідчить про свідому переорієнтацію 3 класичного розуміння художньої творчості на конструювання артефактів-симулякрів, що є характерною ознакою в творчості сучасних художників, починаючи від поп-арту і до сьогодення. Висновки. Реконструкція тіла, перекомутація його елементів за принципом хаотичного колажу, трактування людського тіла як відстороненої від самої людини окремої субстанції, що подається як феномен масової культури стала основою творчого методу сучасного пластичного мистецтва. Ідеї філософів-постмодерністів знайшли своє візуальне втілення в сучасних мистецьких практиках.

Ключові слова: тілесність; людина; скульптура; класичне мистецтво; модернізм; постмодернізм; художній образ 


\section{Р. М. РУСИН ${ }^{1 *}$, И. В. ЛЯШЕНКО ${ }^{2 *}$}

1*Киевский национальный университет имени Тараса Шевченко (Киев, Украина), эл. почта rusinr71@gmail.com, ORCID 0000-0003-4102-0924

${ }^{2 *}$ Киевский национальный университет имени Тараса Шевченко, (Киев, Украина), эл. почта irina_lyashenko@univ.net.ua, ORCID 0000-0003-3912-2075

\section{ЕВРОПЕЙСКОЕ ПЛАСТИЧЕСКОЕ ИСКУССТВО В АНТРОПОЛОГИЧЕСКОМ ИЗМЕРЕНИИ: ОТ КЛАССИКИ К ПОСТМОДЕРНИЗМУ}

Цель. В статье анализируется телесность как атрибутивный признак пластического искусства в Античном искусстве, Средневековье, Ренессансе, модернизме и постмодернизме. Теоретический базис. Историческое развитие искусства рассматривается как смена парадигм. В рамках каждой парадигмы вырабатывается особое понимание искусства, которое характеризуется как собственно творческим актом, так и оценкой его результатов. Особенно актуальной есть задача выявить истоки этих изменений, обозначить их этапы, определить направленность эволюции художественного творчества. В этом контексте телесность как парадигма европейского пластического искусства рассматривается в статье в конкретно-историческом измерении от классики к постмодернизму. Научная новизна. Постмодернистские эксперименты стимулируют стирание границ между традиционными видами и жанрами искусства. Просмотр канонических представлений о создании и разрушении, порядке и хаосе в искусстве свидетельствует о сознательной переориентации с классического понимания художественного творчества на конструирование артефактов-симулякров, что является характерным признаком в творчестве современных художников, начиная от поп-арта до сегодняшнего дня. Выводы. Реконструкция тела, перекоммутация его элементов по принципу хаотического коллажа, трактовка человеческого тела как отстраненной от самого человека отдельной субстанции, стала основой творческого метода современного пластического искусства. Идеи философов-постмодернистов нашли свое визуальное воплощение в современных художественных практиках.

Ключевые слова: телесность; человек; скульптура; классическое искусство; модернизм; постмодернизм; художественный образ

Received: 01.04.2018

Accepted: 22.11.2018 